3

(3)

3

15

17

9

\section{How scars shape the neural landscape: key molecular mediators of TGF- $\beta 1$ 's anti-neuritogenic effects}

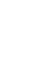

\author{
Kye-Im Jeon ${ }^{1,2}$ and Krystel R. Huxlin ${ }^{1,2^{*}}$
}

${ }^{1}$ The Flaum Eye Institute, University of Rochester, Rochester, NY, USA

${ }^{2}$ The Center for Visual Science, University of Rochester, NY, USA

*Correspondence: Dr. Krystel R. Huxlin, Flaum Eye Institute, University of Rochester Medical Center;

210 Crittenden Blvd, Box 314, Rochester, NY 14642, USA; phone +1-(585) 275-5495; email:

khuxlin@ur.rochester.edu

Short title: TGF- $\beta 1$ signaling in neurons

Key words: wound healing, neurite outgrowth, GSK-3 $\beta$, CRMP2, NGF, Smad3

Declaration of interests: The authors have declared that no conflict of interest exists

Data availability statement: Raw data is available at https://figshare.com/s/02e079a2699fb139977c 


\section{Abstract}

Following injury to the peripheral and central nervous systems, tissue levels of transforming

27 growth factor (TGF)- $\beta 1$ often increase, which is key for wound healing and scarring. However, active wound regions and scars appear to inhibit process outgrowth by regenerating neurons. We recently showed that corneal wound myofibroblasts block corneal nerve regeneration in vivo, and sensory neurite outgrowth in vitro in a manner that relies critically on TGF- $\beta 1$. In turn, delayed, abnormal reinnervation contributes to long-term sensory dysfunctions of the ocular surface. Here, we exposed morphologically and biochemically-differentiated sensory neurons from the ND7/23 cell line to TGF- $\beta 1$ to identify the intracellular signals regulating these anti-neuritogenic effects, contrasting them with those of Semaphorin(Sema)3A, a known inhibitor of neurite outgrowth. Neuronal morphology was quantified using phase-contrast imaging. Western blotting and specific inhibitors were then used to identify key molecular mediators. Differentiated ND7/23 cells expressed neuron-specific markers,

37 including those involved in neurite extension and polarization. TGF- $\beta 1$ increased phosphorylation of collapsin response mediator protein-2 (CRMP2), a molecule that is key for neurite extension. We now show that both glycogen synthase kinase (GSK)-3 $\beta$ and Smad3 modulate phosphorylation of CRMP2 after treatment with TGF- $\beta 1$. GSK-3 $\beta$ appeared to exert a particularly strong effect, which could be explained by its ability to phosphorylate not only CRMP2, but also Smad3. In conclusion, TGF- $\beta 1$ 's inhibition of neurite outgrowth in sensory neurons appears to be regulated through a highly-conserved signaling pathway, which involves the GSK-3ß/CRMP-2 loop via both canonical and non-canonical mechanisms. It is hoped that by defining the signaling pathways that control neurite outgrowth in wound environments, it will become possible to identify optimal molecular targets to promote reinnervation following injury. 
48

\section{Introduction}

Nerve injuries pose many challenges to patients, ranging from mild discomfort to life-long impairment due to pain, loss of sensitivity, motor function and/or autonomic control [1]. While adult peripheral nerves can regenerate, reinnervation does not always recapitulate the original anatomic distributions, nor do all patients with injured nerves regain appropriate functions $[2,3]$. Successful structural and functional regeneration depends on many factors, including the intrinsic growth capacity of the injured cells, the presence of a local, permissive environment and appropriate axonal guidance cues [4-6].

Wound environments are not generally permissive to nerve regeneration. One factor that contributes to this phenomenon is transforming growth factor (TGF)- $\beta 1$, which is normally present at low levels in intact peripheral and central nervous systems, but increases massively both proximal and distal to injury sites $[7,8]$. TGF- $\beta 1$ controls master switches for key events in extracellular matrix formation and wound healing $[9,10]$, via both canonical small mothers against decapentaplegic (Smad) signaling and noncanonical pathways [11]. The increased expression of TGF- $\beta 1$ after injury plays positive roles by regulating the immune response, modulating neuronal phenotype and regulating expression of growth factors important for neuronal repair [12-14]. However, TGF- $\beta 1$ also stimulates the formation of fibrotic scars at the lesion site ; this can be problematic for nerve regeneration, as scar-forming cells can inhibit regrowth, plasticity and recovery of damaged neurons [15-18]. Scar formation is particularly detrimental in the cornea, where it decreases transparency and the ability to see. The cornea is also interesting in the context of TGF- $\beta 1$-regulated scarring, because it is the most densely innervated peripheral tissue in the human body [19]. Corneal nerves arise from the trigeminal ganglion, are distributed through the anterior half of the stroma and the epithelium, are predominantly mechanosensory and nociceptive, and serve to protect the eye from outside elements [20-22]. Although corneal nerves are part of the peripheral nervous system and able to regenerate, wounding of the cornea often results in abnormal reinnervation, with surprisingly serious and long-lasting effects [23-30]. We recently showed that corneal myofibroblasts, which differentiate largely from stromal keratocytes in and around the wound site [31], inhibit the regrowth of corneal nerves into the wound area $[16,18]$. Importantly, this effect was reproduced in vitro: when corneal myofibroblasts were co-cultured with neurons derived from the ND7/23 cell line, they inhibited neurite outgrowth [16]. Importantly, TGF- $\beta 1$ was shown to be both necessary and sufficient for this anti-neuritogenic effect of myofibroblasts [16], allowing us to now use this growth factor as a surrogate [in place of myofibroblasts] to define molecular pathways that 
inhibit neurite outgrowth in pure neuronal cultures (i.e., cell-autonomously).

Neurites are defined as projections from the filopodia or lamellipodia of a neuron, which can subsequently become polarized into an axon or dendrite [32,33]. During their elaboration, neurites undergo stereotypical changes [34] that rely on the response of the intracellular cytoskeleton to a variety of extracellular cues, including secreted factors [33]. Microtubules, cylindrical polymers composed of $\alpha$ - and $\beta$-tubulin heterodimers, are the primary cytoskeletal elements forming the core of cylindrical neurites [35]. Collapsin-response mediator protein-2 (CRMP2) functions as a carrier of free tubulin heterodimers [36], which it delivers to the assembly-plus ends of nucleating sites in growing microtubules, consequently promoting acetylation and neurite extension. We previously reported that TGF- $\beta 1$-induced reduction in neurite outgrowth by ND7/23 cells is associated with increased phosphorylation of CRMP2 [16]. Glycogen synthase kinase (GSK)-3 $\beta$-mediated CRMP2 phosphorylation prevents its binding to tubulin heterodimers [37], thus regulating microtubule dynamics and neuronal polarization [38]. GSK-3s are Ser/Thr protein kinases whose GSK-3 $\alpha$ and GSK-3 $\beta$ isoforms are ubiquitously expressed [39] and play important roles in fundamental cellular processes such as differentiation, proliferation, motility and inflammation [40]. The present set of experiments tested the hypothesis that the inhibitory effects of TGF- $\beta 1$ on neurite outgrowth occur through activation (i.e., dephosphorylation) of GSK-3 $\beta$ and that this is the key event causing increased CRMP2 phosphorylation, and consequently, decreased neurite elongation. Building on our prior work [16], we chose to test this hypothesis in ND7/23 cells, which are created by fusing N18tg2 mouse neuroblastoma cells and neonatal rat dorsal root ganglion cells [41]. This hybrid cell line is often used as an immortalized proxy for peripheral [including corneal] sensory neurons because its cells can be readily differentiated by addition of nerve growth factor (NGF) [42-44]. Differentiated ND7/23 neurons extend neurites and express molecular markers that identify them as A-fiber mechano-sensors and C-fibers [45] - two major classes of sensory nerves found in the cornea and other peripheral tissues. 
105

106

107

108

109

110

111

112

113

114

115

116

117

118

119

120

121

122

123

124

125

126

127

128

129

130

131

132

133

134

135

\section{Materials and methods}

Culture and priming of ND7/23 cells: The neuronal hybridoma cell line ND7/23 (Sigma Aldrich, St. Louis, MO) was maintained in Dulbecco's modified Eagle's medium (DMEM) (D6046; Sigma Aldrich) with 10\% [vol/vol] of fetal bovine serum (FBS; Sigma Aldrich) + 1\% [vol/vol] penicillin/streptomycin (Corning Inc., Corning, NY). Cells were multiplied until passage 10 (freshly thawed cells were considered passage 1). They were passaged by trypsinization (Corning Inc.) every 3-5 days, when approximately 70-90\% confluent. Cells were seeded at a density of $5 \times 10^{4} / \mathrm{cm}^{2}$. After attachment, they were washed twice with 1x Dulbecco's phosphate-buffered saline (dPBS; Thermo Fisher Scientific, Waltham, MA) and with serum free medium (SFM) and then incubated with SFM for 1 day to inhibit mitosis before adding nerve growth factor (NGF) $[46,47]$. Such SFM-primed cells were used in all experiments below, unless otherwise specified.

Phenotypic characterization of SFM-primed ND7/23 cells after NGF treatment: Recombinant rat NGF (rNGF, 556-NG-100, R\&D Systems Inc. Minneapolis, MN) was used to induce differentiation and neurite outgrowth in SFM-primed ND7/23 cells. SFM-primed ND7/23 cells $\left(6 \times 10^{5}\right.$ cells $/ 6 \mathrm{~cm}$ primaria culture dish, Corning Inc.) were treated with 50ng/ml rNGF + 0.5\% FBS. Phase-contrast images of each culture dish were captured using an inverted Olympus IX73 microscope (Olympus Corporation of the Americas, Center Valley, PA) under 10X magnification at 1, 3, 5 and 7 day(s). Cells were treated with fresh media containing 50ng/ml rNGF every second day. After imaging, western blotting was performed; whole cell lysates were fractionated by sodium dodecyl sulfate-polyacrylamide gel electrophoresis (SDS-PAGE) and transferred to a $0.2 \mu \mathrm{m}$ pore-size nitrocellulose membrane (Millipore- Sigma, Burlington, MA). After transfer, the membrane was cut into separate proteins according to molecular mass, and probed with antibodies against rabbit monoclonal growth associated protein-43 (GAP-43; 1:2000; \#ab75810, Abcam, Cambridge, MA), mouse monoclonal neurofilament light polypeptide (NF-L; 1:1000; sc-20012, Santa Cruz Biotechnology, Dallas, TX), mouse monoclonal antibodies to anti-calcitonin gene-related peptide (CGRP; 1:500; C7113, Sigma Aldrich), rat monoclonal antibodies to substance P (SP, 1:500; MA5-17201, Thermo Fisher), and a mouse monoclonal antibody to acetylated $\alpha$-tubulin (Ac-Tub; 1:5000, 6-11B-1, Santa Cruz Biotechnology). Responsiveness to NGF was assayed by probing for the expression of tropomyosin receptor kinase A (Trk-A; 1:2000; \#06-574, Millipore-Sigma) [48]. Finally, we probed for changes in the expression of signaling molecules that could mediate the anti-neuritogenic effects of TGF- $\beta 1$ on ND7/23 cells: total (t)-GSK-3 $\alpha / \beta$ (mouse monoclonal antibody, 1:2000; sc-7291, Santa Cruz 
Biotechnology), and t-CRMP2 (mouse monoclonal antibody, 0.2ug-0.4ug/ml; C4G, Immuno-Biological Laboratories, Minneapolis, USA). The expression of $\beta$-actin (mouse monoclonal antibody, 1:10,000; sc166729, Santa Cruz Biotechnology) was used as a loading control.

Phenotypic characterization of ND7/23 cells after TGF- $\beta 1$ treatment: To investigate the effects of TGF$\beta 1$ on neuritogenesis, we examined the morphology of ND7/23 cells after 1 day in culture, and measured their relative expression of $\mathrm{pGSK}-3 \beta / \mathrm{tGSK}-3 \alpha / \beta$ and $\mathrm{pCRMP} 2 / \mathrm{tCRMP} 2$ using western blots. As a control, we contrasted the strength of TGF- $\beta 1^{\prime}$ effects with those of Semaphorin $3 A$ (Sema3A), a wellknown inhibitor of neurite extension [49-51]. While earlier studies [49-51] found $4 \mathrm{ng} / \mathrm{ml} \mathrm{Sema3A}$ sufficient to produce $50 \%$ collapse of DRG growth cones, $10 \mathrm{ng} / \mathrm{ml}$ of recombinant Sema3A was necessary to exert a comparable effect in SFM-primed ND7/23 cells and was thus used in all experiments.

Quantitative analysis of neuronal polarity and neurite length: SFM-primed ND7/23 cells $\left(8 \times 10^{4}\right.$ cells $/ 6 \mathrm{~cm}$ primaria culture dish) were pretreated with 1, $10 \mathrm{ng} / \mathrm{ml}$ TGF- $\beta 1$ (240-B-010, R\&D Systems) or 10ng/ml Sema3A (1250-S3-025,R\&D Systems). After $1 \mathrm{hr}$, either $0.5 \mathrm{ng} / \mathrm{ml}$ or $50 \mathrm{ng} / \mathrm{ml} \mathrm{rNGF}$ (R\&D Systems) was added for 1 day. Phase-contrast images were captured using an inverted Olympus IX73 microscope (Center Valley, PA) under 20X magnification. A 19-hole imaging template was used for analysis, covering $\sim 8.6 \%$ of the dish area and $\sim 100$ cells/dish. The development of polarity by cultured cells can be divided into 5 stages [34, 35], but only stages 1 to 3 were evident after 1 day in our culture system (see examples in Fig. 2A-C). In Stage 1, short neurites emerge from the cell body, extending as protrusions and lamellipodia (lamellipodial veil). In Stage 2, some lamellipodia are replaced by short (less than $10 \mu \mathrm{m})$ neurites, which appear as flattened processes with extensive, protrusive activity at their tips. In Stage 3, one of these neurites elongates at a faster rate, developing into an axon-like process (at least $10 \mu \mathrm{m}$ longer than the other neurites) [52], causing the neuron to become polarized. The CellSens imaging software (Olympus CellSens Standard ver. 1.12, Olympus) was used to manually tag and count the number of cells in Stages 1, 2 and 3 in each of the 19 photographs taken for each culture plate. For each of the neurons in Stages 2 and 3, we then traced and measured the length of neurites extruded using the CellSens imaging software. From these tracing, we counted the number of neurites $>40 \mu m$ in length (two-fold longer than the average diameter of a cell soma) per image. These analyses allowed us to evaluate the neuronal differentiation attained following exposure to different factors, as well as the proclivity for significant (>40 $\mathrm{m}$ long) neurite extension. 
Effect of TGF- $\beta 1$ on GSK-3 $\beta$ signaling in ND7/23 cells: Passage 5 , SFM-primed cells $\left(3 \times 10^{5}\right.$ cells $/ 35 \mathrm{~mm}$ dish) were treated with $50 \mathrm{ng} / \mathrm{ml}$ rNGF in $0.5 \%$ FBS-DMEM for 1 day. They were then washed with $1 \mathrm{x}$ dPBS and incubated in 0.5\% FBS-DMEM. After 30min, cells were pretreated with either $10 \mathrm{ng} / \mathrm{ml}$ of TGF-

$172 \beta 1$ or $10 \mathrm{ng} / \mathrm{ml}$ Sema3A (as a positive control) for $30 \mathrm{~min}$ before adding either $0.5 \mathrm{ng} / \mathrm{ml}$ or $100 \mathrm{ng} / \mathrm{ml}$ rNGF for $1 \mathrm{hr}$. The cells were processed for western blots, which were stained using a rabbit polyclonal anti-pGSK-3 $\beta_{\text {Ser-9 }}$ antibody (1:2000; D85E12, Cell Signaling Technology) to detect and quantify the expression of $p-G S K-3 \beta$ relative to that of mouse monoclonal (total) t-GSK-3 $\alpha / \beta$ (1:2000; SC-7291 Santa Cruz Biotechnology).

To determine if GSK-3 $\beta$ activity was a key regulator of CRMP2 phosphorylation, we used the natural GSK-3 $\alpha / \beta$ inhibitor, lithium chloride (LiCl), to block its activity [53]. Passage 4-6, SFM-primed cells $\left(3 \times 10^{5}\right.$ cells $/ 35 \mathrm{~mm}$ dish) were treated with $50 \mathrm{ng} / \mathrm{ml} \mathrm{rNGF}$ in $0.5 \%$ FBS-DMEM for 1 day. The cells were then washed and pretreated with $10 \mathrm{ng} / \mathrm{ml} \mathrm{TGF- \beta 1}$ or $10 \mathrm{ng} / \mathrm{ml}$ Sema3A with/without $10 \mathrm{mM} \mathrm{LiCl}$ (Sigma Aldrich) for $1 \mathrm{hr}$. Finally, the cells were incubated with $100 \mathrm{ng} / \mathrm{ml}$ rNGF for 1 day before western (see above, Immuno-Biological Laboratories). mediators of TGF- $\beta 1$ 's actions [11], Smad2 lacks a commercially-available, specific inhibitor. As such, we focused our studies on the contributions of Smad3 by employing SIS3 (Specific Inhibitor of Smad3), which specifically blocks activation of Smad3 [54]. Passage 4-6 SFM-primed cells ( $3 \times 10^{5} \mathrm{cells} / 35 \mathrm{~mm}$ dish) were incubated with $50 \mathrm{ng} / \mathrm{ml} \mathrm{rNGF}$ for 1 day, then washed and pretreated with $10 \mathrm{ng} / \mathrm{ml}$ TGF- $\beta 1$ with/without $1 \mu \mathrm{M}$ of SIS3 (Sigma Aldrich) or $10 \mathrm{mM} \mathrm{LiCl} \mathrm{(Sigma} \mathrm{Aldrich),} \mathrm{the} \mathrm{GSK-3 \beta} \mathrm{blocker,} \mathrm{for} 1 \mathrm{hr}$. Higher concentrations of SIS3 $(2.5,5$ and $10 \mu \mathrm{M})$ proved cytotoxic to ND7/23 cells cultured for 1 day and were therefore not used in the present experiments. Finally, 100ng/ml rNGF was added before harvesting and western blotting to check for the expression of $\mathrm{p}-\mathrm{GSK}-3 \beta / \mathrm{t}-\mathrm{GSK}-3 \alpha / \beta$ and of $\mathrm{pCRMP} 2 / \beta$ actin (see above for antibodies used). 
bioRxiv preprint doi: https://doi.org/10.1101/2020.07.28.224469; this version posted July 28, 2020. The copyright holder for this preprint (which was not certified by peer review) is the author/funder, who has granted bioRxiv a license to display the preprint in perpetuity. It is made available under aCC-BY 4.0 International license.

199 only two groups were compared, two-tailed paired or unpaired Student's t-tests were performed. A 200 probability of error of $P<0.05$ was considered statistically significant. 


\section{Results}

\section{ND7/23 cells become neuron-like after sequential treatment with SFM and rNGF}

When cultured with $10 \%$ FBS/DMEM, ND7/23 cells proliferated rapidly, with a strong tendency to form clumps that were loosely attached to the culture dish and occasionally became free-floating (Fig. 1A). When FBS was removed from the culture medium to block proliferation, the majority of the attached, clumped cells spread into a monolayer. After 1day of addition of rNGF, the cells began to display clear neurite outgrowth, with the majority belonging to the Stage 1 phenotype. Over ensuing days, an increasing proportion of ND7/23 cells transitioned to Stage 2 or Stage 3 morphologies (Fig. 1B), similar to DRG neurons in culture [55]. After 7 days, ND7/23 cell cultures developed aggregations of rounded, phase-bright cell bodies and an extensive network of dendrites that spread over the culture dishes' surface between these aggregations (Fig. 1C).

Fig 1. Phenotypic characterization of differentiated ND7/23 cells. (A) Phase-contrast image of ND7/23 cells cultured under 10\% FBS/DMEM (control) conditions (see lane 1 in D). (B) Phase-contrast image of ND7/23 cells cultured in SFM (Serum-Free Medium) for 1 day, then re-plated with 0.5\% FM (FBS+DMEM) $+50 \mathrm{ng} / \mathrm{ml} \mathrm{rNGF}$ for 1 day (lane 3 in D). (C) Phase-contrast photograph of ND7/23 cells cultured in SFM for 1 day, then re-plated in 0.5\% FM +50ng/ml rNGF for 7 days (lane 6 in D). (D) Representative Western blots of ND7/23 cells treated with 10\% FBS/DMEM (lane 1, Cont.), or grown in SFM for 1 day (lane 2) or in $0.5 \% \mathrm{FM}+50 \mathrm{ng} / \mathrm{ml} \mathrm{rNGF}$ for 1 , 3, 5, or 7 days (lanes 3-6). The relative expression of TrkA, GAP43, acetylated $\alpha$-tubulin (Ac-Tub), NF-L, CGRP, substance $P$, and t-CRMP2 all increased when cells were exposed to $r N G F$, albeit at different rates. $t$-GSK3 $\alpha / \beta$ expression appeared relatively stable. 8 -actin was used as a loading control.

We then asked if the morphological changes observed in ND7/23 cells were accompanied by the appearance of neuron-specific markers and molecules involved in neurite extension and polarization. Compared to undifferentiated ND7/23 cells (grown in 10\% FBS, lane 1, Fig. 1D), culture in SFM for 1 day caused an upregulation of GAP-43, Ac-Tub and CGRP (lane 2, Fig. 1D). Even more dramatic changes were seen in these molecules after rNGF was added (lanes 3-6, Fig. 1D). The relative expression of the NGF receptor TrkA was only seen to increase after addition of rNGF (lanes 3-6, Fig. 1D). NF-L and t-CRMP2 increased more slowly, peaking at 7 days in culture (lane 6, Fig. 1D). Although substance P was not expressed by proliferating cells (lane 1, Fig. 1D) and did not appear during the first 4 days of culture with rNGF (lanes 3-4, Fig. 1D), it was induced in detectable amounts after 5 and 7 days in culture (lanes 5-6, Fig. 1D). In contrast, the expression of t-GSK-3 $\beta$ and $\beta$-actin (the loading control) remained relatively unchanged throughout (lanes 1-6, Fig. 1D). 


\section{Impact of TGF- $\beta 1$ on neurite outgrowth}

Having first established that differentiated ND7/23 cells express both TGF- $\beta$ RI and TGF- $\beta R$ II in their soma and neurites (S1 Fig.), we then assessed how TGF- $\beta 1$ impacted neurite outgrowth. When SFM-primed ND7/23 cells were cultured for 1 day with minimal $(0.5 \mathrm{ng} / \mathrm{ml}) \mathrm{rNGF}$, the majority $(\sim 80 \%)$ of cells that extruded processes were in Stage 1 (Fig. 2A), with the remaining 20\% evenly divided between Stages 2 and 3 (Fig. 2B and C). If instead, these cells were cultured with 50ng/ml rNGF for 1 day, the proportion of cells in Stage 1 decreased (two-tailed paired t-test for 0.5 versus $50 \mathrm{ng} / \mathrm{ml}$ rNGF conditions: $t_{3}=4.33$, $p=0.023$ ), while the proportion of Stage 3 cells nearly doubled (two-tailed paired t-test: $t_{3}=3.58$, $p=0.037$ ) - see pictures in Fig. 2E. The proportion of Stage 2 cells remained unchanged (two-tailed paired t-test: ns). Addition of $1,10 \mathrm{ng} / \mathrm{ml} \mathrm{TGF-} \beta 1$ or $10 \mathrm{ng} / \mathrm{ml}$ Sema3A to cultures exposed to $50 \mathrm{ng} / \mathrm{ml}$ rNGF for 1 day maintained $>80 \%$ of the cells in Stage 1 and kept the proportion in Stage 3 below 10\%, in essence negating the impact of adding rNGF (Fig. 2A-C, E). There were no significant differences between these 3 treatments $(1,10 \mathrm{ng} / \mathrm{ml} \mathrm{TGF-} \beta 1$ or $10 \mathrm{ng} / \mathrm{ml}$ Sema3A) and the low rNGF condition: a two-way ANOVA with repeated measures on 1 factor (Stages) showed no significant effect of treatment $\left(F_{3}=0.28, p=0.84\right)$, a significant effect of Stage ( 1 versus $\left.3, F_{1}=1628.35, p<0.0001\right)$ and no significant interaction between the two $\left(F_{3}=0.48, p=0.703\right)$. Finally, the number of neurites of lengths $40-149 \mu \mathrm{m}$ paralleled the proportion of cells in Stage 3 in each treatment group (Fig. 2D). There were significantly more neurites $40-149 \mu \mathrm{m}$ in length when ND7/23 cells were cultured with 50 than with $0.5 \mathrm{ng} / \mathrm{ml} \mathrm{rNGF}$; a two-way ANOVA with repeated measures on neurite length $(40-49 \mu \mathrm{m}, 50-99 \mu \mathrm{m}$ or $100-149 \mu \mathrm{m})$ showed a significant effect of neurite length category $\left(F_{2}=20.64, p=0.00013\right)$, of treatment $\left(F_{1}=27.42, p=0.0019\right)$ and no significant interaction $\left(F_{2}=1.32, p=0.303\right)$. Neurites longer than $150 \mu \mathrm{m}$ were very rare and their incidence appeared not to change dramatically under different treatment conditions (Fig. 2D). Overall, the number of neurites $>40 \mu \mathrm{m}$ went from $22.5 \pm 3.3 /$ plate in $0.5 \mathrm{ng} / \mathrm{ml} \mathrm{rNGF}$ to $45.8 \pm 8.7 /$ plate in $50 \mathrm{ng} / \mathrm{nl}$ rNGF. Addition of $1,10 \mathrm{ng} / \mathrm{ml} \mathrm{TGF- \beta 1}$ or $10 \mathrm{ng} / \mathrm{ml} \mathrm{Sema3A}$ to ND7/23 cells cultured with $50 \mathrm{ng} / \mathrm{ml} \mathrm{rNGF}$ negated the impact of rNGF on neurite outgrowth, with total number of neurites $>40 \mu \mathrm{m}$ remaining around $20 /$ plate, not significantly different than in the $0.5 \mathrm{ng} / \mathrm{ml}$ rNGF condition (one-way ANOVA: $F_{3}=0.84, p=0.4999$ ). All in all, TGF- $\beta 1$ appeared to have a similar effect on neuritogenesis as Sema3A.

Fig 2. Inhibitory effect of TGF-B1 on neurite extension in differentiated ND7/23 cells. (A) Plot of percentage of cells counted that exhibited Stage 1 morphology when cultured with different concentrations of rNGF, TGF-B1 or Sema3A. Note the significant drop in the proportion of Stage 1 cells exposed to $50 \mathrm{ng} / \mathrm{ml} \mathrm{rNGF}$ relative to all other conditions. Inset shown typical morphology of Stage 1 
ND7/23 neuron. (B) Plot of percentage of cells counted that exhibited Stage 2 morphology under different culture conditions, as in $A$. The proportion of Stage 2 cells remained relatively unchanged across conditions. Inset shown typical morphology of Stage 2 ND7/23 neuron. (C) Plot of percentage of cells counted that exhibited Stage 3 morphology under different culture conditions, as in A and B. Inset shown typical morphology of Stage 3 ND7/23 neuron. Note the significant increase in the proportion of Stage 3 cells after exposure to $50 \mathrm{ng} / \mathrm{ml} \mathrm{rNGF}$ and the lack of such increase in cells treated with NGF+TGF-B1 or Sema3A. (D) Plot of the number of neurites of different lengths per plate of ND7/23 cells grown under the same culture conditions as in A-C. Note the general increase in the number of neurites of all lengths $>50 \mu \mathrm{m}$ long when cells are treated with $50 \mathrm{ng} / \mathrm{ml} \mathrm{rNGF}$, and the lack of such increase when the cells are treated with additional TGF-B1 or Sema3A. E. Illustrations of phenomena shown in A-D using phasecontrast photographs of cultured ND7/23 cells treated either with $50 \mathrm{ng} / \mathrm{ml} \mathrm{rNGF}$, or with $50 \mathrm{ng} / \mathrm{ml}$ rNGF+1 ng/ml TGF-81, or with 50ng/ml rNGF+ $10 \mathrm{ng} / \mathrm{ml}$ Sema3A. Graphs in A-D show means and standard deviations, with $n=4$ in all cases except for the Sema $3 A$ conditions, for which $n=3$.

\section{Effect of TGF- $\beta 1$ on intracellular signals associated with neurite outgrowth}

Consistent with the notion that GSK-3 $\beta$ activity is a key regulator of NGF's neuritogenic effects [56] (S2

Fig.), $100 \mathrm{ng} / \mathrm{ml}$ rNGF dramatically increased levels of p-GSK-3 $\beta$ (the inactive form) while leaving levels of t-GSK relatively unaffected (Fig. 3A, B - lane2). As a result, there was a significant increase in the ratio of

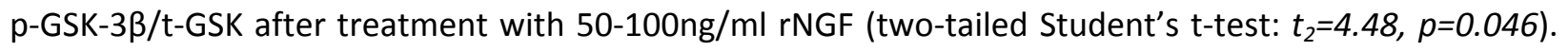
Of note, the rNGF-induced increase in p-GSK-3 $\beta /$ t-GSK ratio could be blocked effectively by the addition of $0.6 \mu \mathrm{g} / \mathrm{ml}$ anti-NGF antibody (S2 Fig.).

Fig 3. Modulation of GSK3B activity by TGF-61 and Sema3A. (A) Representative Western blot of SFMprimed ND7/23 cells treated with different concentrations of rNGF with or without TGF- 61 or Sema3A and probed with antibodies against phosphorylated GSK-3B (at Ser9) or total GSK-3 $\alpha / B$. Levels of phosphorylated (i.e. inactive) GSK-3B (lane 2) are increased after treatment with $100 \mathrm{ng} / \mathrm{ml} \mathrm{rNGF}$ compared to $0.5 \mathrm{ng} / \mathrm{ml} \mathrm{rNGF}$ (lane1). Both $10 \mathrm{ng} / \mathrm{ml}$ TGF- 81 and $10 \mathrm{ng} / \mathrm{m} /$ Sema3A blocked this increased phosphorylation of GSK-3B. (B) Plot of the ratio of $p-G S K-36 / t-G S K-3 \alpha / 6$ normalized to levels obtained following stimulation with $100 \mathrm{ng} / \mathrm{ml} \mathrm{rNGF}$ and under the different conditions shown in $A$. Data are means \pm standard deviations. (C) Representative Western blot of SFM-primed ND7/23 cells treated with $100 \mathrm{ng} / \mathrm{ml}$ rNGF alone (lane 1), or with TGF- $B 1$ or Sema3A with and without lithium chloride (LiCl), a blocker of GSK-3B activity (see Fig. 5). Both TGF- 11 and Sema3A cause an increase in levels of phosphorylated ( $p$ )-CRMP2 compared to total (t)-CRMP2 levels (compare lane1 with lanes 2,3). Pretreatment with LiCl (lanes 4 and 5), which maximally phosphorylates (i.e. inactivates) GSK-3B prior to the addition of TGF- 61 or Sema3A completely blocks the ability of these two molecules to generate $p$ CRMP2. (D) Plot of the ratio of $p$-/t-cRMP2 measured from blots such as those shown in $C$ and normalized to lane 2 (10ng/m/ TGF- 61 condition). Values are means \pm standard deviations.

Critical to our goals, addition of $10 \mathrm{ng} / \mathrm{ml} \mathrm{TGF- \beta 1} \mathrm{or} \mathrm{10ng/ml} \mathrm{Sema3A} \mathrm{(Fig.} \mathrm{3A,} \mathrm{B)} \mathrm{to} \mathrm{SFM} \mathrm{-primed}$ ND7/23 cells cultured with $100 \mathrm{ng} / \mathrm{ml}$ rNGF were about equally effective at blocking the relative increase in $p$-GSK-3 $\beta$. In fact, when the ratio of $p-G S K-3 \beta / t-G S K$ was normalized to levels attained following 
stimulation with $100 \mathrm{ng} / \mathrm{ml} \mathrm{rNGF}$, there was no significant difference between the effects of TGF- $\beta 1$ and Sema3A (Fig. 3B, two-tailed Student's t-test: $t_{4}=0.55, p=0.612$ ), both causing about a $30 \%$ reduction. A one-way ANOVA comparing these 3 groups confirmed this, revealing a main effect of treatment $\left(F_{(2,4)}=28.8, p=0.00422\right)$ with post-hoc Tukey HSD tests showing significant differences between $\mathrm{rNGF}$ and rNGF+TGF- $\beta 1(p<0.01)$, as well as between rNGF and rNGF+Sema3A $(p<0.01)$, but not between rNG+TGF- $\beta 1$ and rNGF+Sema3A.

Our prior works showed that TGF- $\beta 1$ stimulation regulates phosphorylation of CRMP2 in ND7/23 cells [16]. Here, we replicated this result, showing that addition of $10 \mathrm{ng} / \mathrm{ml}$ TGF- $\beta 1$ or $10 \mathrm{ng} / \mathrm{ml}$ Sema3A to SFM-primed ND7/23 cells cultured with $100 \mathrm{ng} / \mathrm{ml} \mathrm{rNGF}$ were equally effective at increasing levels of p-CRMP2, doing so by about 1.5 -fold (Fig. 3C, D). In fact, when the ratio of p-CRMP2/t-CRMP2 was normalized to levels attained following stimulation with $100 \mathrm{ng} / \mathrm{ml} \mathrm{rNGF}$, there was no significant difference between the effects of $10 \mathrm{ng} / \mathrm{ml}$ of TGF- $\beta 1$ and 10ng/ml Sema3A (Fig. 3D, two-tailed Student's t-test: $\left.t_{4}=0.04, p=0.970\right)$.

Since GSK-3 $\beta$ is a candidate kinase thought to regulate CRMP2 phosphorylation and thus, its activity [37], the prediction is that when TGF- $\beta 1$ and Sema3A decrease $p-G S K-3 \beta$ in ND7/23 cells, this should be associated with a corresponding increase in levels of $p-C R M P 2$. Indeed, when SFM-primed ND7/23 cells were treated with $100 \mathrm{ng} / \mathrm{ml}$ rNGF, the ratio of $p-G S K-3 \beta / t-G S K-3 \beta$ increased (lane 2, Fig. 3A, B), levels of p-CRMP2 were relatively low (lane 1, Fig. 3C, D). In other words, CRMP2 was in its active (nonphosphorylated) form, associated with neurite extension (see Introduction, Fig. 5). When either 10 $\mathrm{ng} / \mathrm{ml} \mathrm{TGF-} \beta 1$ or $10 \mathrm{ng} / \mathrm{ml}$ Sema3A were added, the relative levels of $\mathrm{p}-\mathrm{GSK}-3 \beta$ decreased (Fig. 3A-B) and those of p-CRMP2 increased (Fig. 3C-D). Because levels of total GSK and CRMP2 remained relatively unchanged, we concluded that an inverse relationship exists between levels of p-GSK-3 $\beta$ and p-CRMP2 in differentiated ND7/23 cells.

We then critically tested this hypothesis using lithium chloride (LiCl), a natural GSK-3 $\alpha / \beta$ inhibitor, which is thought to work by activating an upstream protein kinase (AKT) and blocking protein phosphatases - actions that ultimately saturate the phosphorylation of GSK-3 $\alpha / \beta$ on Ser 21/9 [53]. We verified that pre-treatment of ND7/23 cells with $10 \mathrm{mM} \mathrm{LiCl}$ blocked the ability of both TGF- $\beta 1$ and

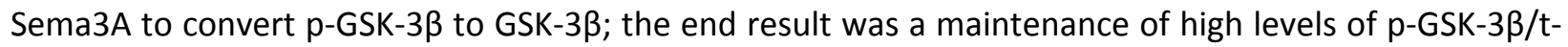
GSK-3 $\beta$ in the cells (lanes 4 and 5, Fig. 3C). Associated with this effect, LiCl completely blocked the ability of both TGF- $\beta 1$ and Sema3A to increase p-CRMP2 relative to t-CRMP2 (compare lane 2-3 with lanes 4-5, Fig. 3C, D). A one-way ANOVA for $\mathrm{p}-/ \mathrm{t}$-CRMP2 ratios across all treatment groups in this experiment showed a significant main effect of treatment $\left(F_{(4,8)}=8.3, p=0.006\right)$, with post-hoc Tukey HSD tests 
confirming significant differences between TGF- $\beta 1$, Sema3A and TGF- $\beta 1+\mathrm{LiCl}$, Sema3A+LiCl conditions ( $p<0.05$ in all cases). Therefore, it appears that levels of $p$-GSK-3 $\beta$ and $p$-CRMP2 are inversely and causally linked in ND7/23 cells, and that manipulations which either increase (e.g. LiCl) or decrease (e.g. TGF- $\beta 1$, Sema3A) p-GSK-3 $\beta$ levels impact $p-C R M P 2$.

\section{Relative importance of Smad3 for TGF- $\beta 1$ 's effect on $p$-CRMP2}

Since Smad2/3 signaling is a canonical mediator of TGF- $\beta 1$ 's actions, we asked what role this pathway may play in TGF- $\beta 1$ 's ability to modulate levels $p$-CRMP2 and p-GSK-3 $\beta$ in differentiated ND7/23 cells. First, we noted that TGF- $\beta 1$ and NGF appeared to influence different phosphorylation sites on Smad3 (compare lanes 1 and 2, S3 Fig.). For instance, TGF- $\beta 1$ appeared to modulate phosphorylation of Smad3 on Ser-204, but not on Ser-423/425. Furthermore, the Smad3 inhibitor SIS3 blocked Smad3 phosphorylation by TGF- $\beta 1$ but not NGF (compare lanes 2 and 3, S3 Fig.). LiCl, which blocks GSK-3 $\beta$ activity, blocked phosphorylation of Smad3 on both Ser-423/425 and Ser-204, while application of SIS3 failed to alter levels of p-GSK-3 $\beta$ (lanes 1-3, Fig. 4A, C; see also S4 Fig.); however, SIS3 did prevent TGF$\beta 1$ from raising p-CRMP levels above baseline (lanes 1-3, Fig. 4A, B). In fact, a two-tailed t-test revealed no significant difference in the levels of $p$-CRMP2/ $\beta$-actin in ND7/23 cells at baseline (i.e., cultured in $100 \mathrm{ng} / \mathrm{ml} \mathrm{rNGF})$ and after treatment with TGF- $\beta 1+S I S 3\left(t_{4}=1.04, p=0.357\right)$. Nonetheless, the GSK-3 $\beta$ inhibitor LiCl exerted a much stronger inhibitory effect on p-CRMP2 than SIS3, causing levels p-CRMP2 to drop about 4-fold below baseline levels and about 7-fold below levels induced by TGF- $\beta 1$ stimulation (lane 4, Fig. 4A, B). A one-way ANOVA across all treatment groups shown in Fig. 4 revealed a significant main effect of treatment $\left(F_{(3,6)}=15.55, p=0.0031\right)$ with post-hoc Tukey's tests confirming significant differences in normalized $p$-CRMP2 levels between baseline $(100 \mathrm{ng} / \mathrm{ml} \mathrm{rNGF})$ and TGF- $\beta 1+\mathrm{LiCl}(p<0.05)$, as well as between TGF- $\beta 1$ and TGF- $\beta 1+$ SIS3 $(p<0.05)$ and between TGF- $\beta 1$ and TGF- $\beta 1+L i C L(p<0.01)$. In summary, canonical Smad2/3 signaling does appear to contribute to TGF- $\beta 1$ 's anti-neuritogenic effect in ND7/23 cells, but its contribution is smaller than that from GSK-3 $\beta$.

Fig 4. SIS3 decreases phosphorylation of CRMP2 without activating GSK-36. (A) Representative Western blot of SFM-primed ND7/23 cells pretreated with SIS3 (lane 3) and LiCl (lane 4) with TGF- 61 and probed with antibodies against phosphorylated CRMP2 and GSK-36 (at Ser9) or total GSK-3a/B. Note that $1 \mu M$ SIS3 significantly reduced levels of $p$-CRMP2 (lane 3 ) without affecting levels of $p$-GSK-3B. (B) Plot of the ratio of $p$-CRMP2/B-actin normalized to levels obtained following stimulation with $10 \mathrm{ng} / \mathrm{ml}$ TGF-B1 (lane 2). b-actin was used as a loading control. (C) Plot of the ratio of $p$-GSK-36/t-GSK-3B normalized to levels obtained following stimulation with 100ng/mI NGF (lane 1). Total GSK-3B was used as a loading control. All plotted data are means \pm standard deviations over 3 experiments. 


\section{Discussion}

377 In the present study, we developed an optimized protocol to generate morphologically and 378 biochemically-differentiated sensory neurons from the ND7/23 cell line. We then used these 379 differentiated neurons to detail the signaling pathways mediating the inhibitory effects of TGF- $\beta 1$ on neurite outgrowth. Specifically, we uncovered that TGF- $\beta 1$ works via both canonical and non-canonical signals, with the latter appearing to exert the strongest influence on CRMP2 phosphorylation, and consequently, neurite elongation.

\section{ND7/23 cells become neuron-like after sequential treatment with SFM and rNGF}

Because our experiments were performed in ND7/23 cells, an immortalized cell line often used as an proxy for peripheral sensory neurons[16, 42-45], it was essential to first attain reliable differentiation of these cells. Neuroblastoma cells express few NGF receptors and can thus have low sensitivity to this growth factor $[57,58]$. We overcame this hurdle by first "starving" ND7/23 cells with SFM for 1 day in order to increase responsiveness to NGF [55]. As a result, cells began to reliably express high levels of TrkA upon subsequent exposure to NGF, sustaining those levels across multiple (up to 7) days in culture. These cells also extended neurites, becoming multipolar (Stage 1), then pseudo-unipolar (Stages 2-3). Neurite extension was associated with increased acetylated $\alpha$-tubulin (necessary for stable microtubule assembly), as well as NF-L. In addition, differentiated cells expressed neuronal markers such as GAP43

394 (associated with growing neurites), CGRP and substance P, which characterize major sub-populations of sensory nerves in the cornea [20]. Thus, in contrast with other neuroblastoma cells, which can extend neurites, but do not become polarized [59], we successfully developed culture conditions that allowed us to differentiate ND7/23 cells into mature, polarized, sensory, peripheral neurons.

Treatment of SFM-primed cells with 50ng/ml rNGF for 1 day decreased the proportion of Stage 1 cells and increased the proportion of Stage 3 cells by a corresponding amount; the proportion of Stage 2 cells remained unaffected. This suggests that NGF caused a proportion of Stage 1 cells to reach Stage 2

401 and almost immediately transition into Stage 3, showing the greatest level of polarization with the 402 extension of an axon-like process. Treatment of these cells with either TGF- $\beta 1$ or Sema3A, even in the presence of $50 \mathrm{ng} / \mathrm{ml} \mathrm{rNGF}$, prevented neurite elongation, and thus cell polarization. As such, there was no decrease in the proportion of Stage 1 cells, nor increase in Stage 3 cells. While we recently showed that ND7/23 cells co-cultured with corneal fibroblasts are sensitive to the effects of TGF- $\beta 1$ [16], the 
cells in our prior publication were not SFM-primed, nor as carefully differentiated and staged as the cells in the present study. As such, we can now confidently state that TGF- $\beta 1$ exert a strong, anti-neuritogenic effect on sensory neurons differentiated from the ND7/23 cell line.

\section{Molecular substrates of TGF- $\beta 1$ 's anti-neuritogenic effects in differentiated, sensory neurons}

We began our investigations by ascertaining that SFM-primed, differentiated ND7/23 cells strongly express both TGF- $\beta R I$ and TGF- $\beta$ RII in their soma and neurites. This confirms a simple molecular initiator for TGF- $\beta 1$ signaling in these neurons, as previously reported for primary sensory neurons [60], and in contrast with some neuroblastoma cells, whose low responsiveness to TGF- $\beta 1$ was due to low levels of its receptor(s) [61]. Our earlier observation that the inhibitory effect of TGF- $\beta 1$ on neurite outgrowth is critically mediated by its receptor [16] is consistent with studies in embryonic hippocampal and human iPSC-derived neurons [62], in cerebellar granule neurons [63], in experimental diabetic neuropathy and in embryonic DRG cells [64]. However, TGF- $\beta 1$ was reported to increase neurite length in differentiated retinal ganglion cells [65], suggesting that the effect of TGF- $\beta 1$ on neuronal morphogenesis may be influenced by cell type, developmental state, health or disease, experimental manipulation, as well as by the local microenvironment. Nonetheless, most of the evidence in both central and peripheral nervous systems suggests that TGF- $\beta 1$ has largely anti-neuritogenic effects, and this is also the case in differentiated neurons from the ND7/23 cell line. In fact, in these cells, present results show that TGF- $\beta 1$ exerted the same level of inhibition on neurite outgrowth as Sema3A [49-51], at the same effective concentration $(10 \mathrm{ng} / \mathrm{ml})$. So how does TGF- $\beta 1$ exert its anti-neuritogenic effect in cultured, sensory neurons?

We previously showed that in ND7/23 cells, TGF- $\beta 1$ increases phosphorylation of CRMP2 [16], a molecule that delivers free tubulin heterodimers to the assembly-plus ends of growing microtubules, thus promoting acetylation and neurite extension [36]. Here, we asked how TGF- $\beta 1$ increased p-CRMP2, taking our cues from primary DRG cells, where Sema3A exerts is anti-neuritogenic effect by increasing GSK-3 $\beta$ activity, causing phosphorylation of CRMP2 [37, 66]. Conversely, neurotrophin-induced axonal outgrowth in hippocampal neurons occurs via decreased GSK-3 $\beta$ activity, which reduces phosphorylation of CRMP2 [37]. As such, it appears that in many neuronal types, CRMP2 is a physiological substrate of GSK-3 $[67,68]$ and that GSK-3 $\beta$ regulates neurite outgrowth through phosphorylation of CRMP2. In ND7/23 cells, treatment with either TGF- $\beta 1$ or Sema3A prevented NGF- 
induced increases in p-GSK-3 $\beta$ levels to a similar extent. Because this caused a simultaneous increase in p-CRMP2, it suggests that modulating GSK-3 $\beta$ activity was key to regulating neurite outgrowth of differentiated ND7/23 cells (Fig.5). Our experiments are the first to show that TGF- $\beta 1$ and Sema3A have comparable anti-neuritogenic effects - via GSK-3 $3 /$ pCRMP2 - in differentiated ND7/23 cells. Additionally, since the effects of TGF- $\beta 1$ and Sema3A were similar in magnitude and operated via the same intracellular pathways in ND7/23 cells as in other neuronal cell types [37,69, 70], we posit that neuritogenesis may be regulated through a very conserved signaling pathway that relies on a GSK3ß/CRMP-2 loop (Fig. 5).

Fig 5. Schematic diagram summarizing signaling pathways that mediate TGF-61's inhibition of neurite outgrowth (in red). The relative roles of GSK-36 and Smad3 in regulating CRMP2 activity are highlighted, as are the putative loci of action of LiCl on GSK-3B and of SIS3 on Smad3 in differentiated ND7/23 cells.

Finally, the actions of TGF- $\beta 1$ in both neurons and other tissues of the body are known to be mediated by canonical Smad2/3 signaling [11]. Although not known to be regulated by TGF- $\beta 1$, Smad1 signaling, which is key for regeneration of peripheral sensory neurons, is critically regulated by GSK-3 $\beta$ [71]. Thus, we also asked if TGF- $\beta 1$ stimulation recruited Smads (specifically Smad3) to mediate its antineuritogenic effects in ND7/23 cells, and how this was related to its regulation of GSK-3 $\beta$ activity. SIS3 did indeed suppress TGF- $\beta 1$-induced phosphorylation of Smad3 in these neurons, just as it does in fibroblasts [54]. However, here, this action prevented TGF- $\beta 1$ from increasing levels of $p-C R M P 2$, without affecting changes in p-GSK-3 $\beta$. In contrast, LiCl, which blocks GSK-3 $\beta$ activity, decreased Smad3 phosphorylation at 2 different sites (impacted by TGF- $\beta 1$ [72] and NGF, respectively). That GSK-3 $\beta$ can phosphorylate Smad3 at Ser-204 was previously reported [72] but its ability to also influence Smad3 phosphorylation at Ser-423/5 is newly described here. Thus, it appears that GSK-3 $\beta$ not only phosphorylates CRMP2 directly, it additionally phosphorylates (and activates) Smad3 (Fig. 5), explaining why LiCl, TGF- $\beta 1$ and other ways of modulating GSK-3 $\beta$ activity have such a strong effect on $p$-CRMP2 and neurite outgrowth. Given that Smad3 is not a kinase, how its phosphorylation causes increased levels of p-CRMP2 in differentiated ND7/23 cells, and whether it is sufficient and necessary, remain to be determined.

In conclusion, the present study used an optimized protocol to generate morphologically and biochemically-differentiated sensory neurons from the ND7/23 line. In these cells, we quantified the anti-neuritogenic effects of TGF- $\beta 1$, contrasting them with those of Sema3A. We identified a key role of GSK-3 $\beta$ and $p$-CRMP2 in mediating the effects of both molecules. The prevalence of a GSK-3 $\beta / C R M P 2$ 
469 loop for regulating neurite extension across a wide range of neuronal types and species, suggests this to

470 be a highly-conserved signaling pathway. Ultimately, it also means that areas of central and peripheral

471 nervous system damage, which are characterized by dramatically-increased levels of TGF- $\beta 1$ relative to

472 the healthy environment, provide a direct, highly-effective inhibitory stimulus to prevent neurons from

473 rapidly innervating (or re-innervating) damaged regions. In the cornea and other tissues where scars

474 form, the region of fibrosis is denuded of sensory nerve endings, and thus, of sensation. This may be

475 necessary initially, to avoid the largely noxious stimulation that may result from exposure to molecules

476 characteristic of the wound environment. However, one could also envisage a time when it would be

477 desirable to restore normal innervation, a situation that also applies to the central nervous system

478 where axons may need to regrow through glial scars. Thus, understanding the key signaling pathways

479 that control neurite outgrowth in wound environments and their seemingly ubiquitous nature across

480 neuronal types, provides optimal molecular targets to promote re-innervation in a wide range of injury 481 conditions. 
bioRxiv preprint doi: https://doi.org/10.1101/2020.07.28.224469; this version posted July 28, 2020. The copyright holder for this preprint (which

was not certified by peer review) is the author/funder, who has granted bioRxiv a license to display the preprint in perpetuity. It is made available under aCC-BY 4.0 International license.

483

484 Acknowledgements: The authors wish to thank Thurma McDaniel for performing the

485 immunohistochemistry in Supplementary Figure 1. We also thank Dr. Keith Nehrke, Thurma McDaniel,

486 Margaret DeMagistris and Christine Callan for constructive comments on the manuscript.

487

488 Funding: This research was supported by the National Eye Institute of the National Institutes of Health

489 (R01 EY015836 and Core Grant P30 EY001319 to the Center for Visual Science) and an unrestricted grant

490 to the University of Rochester's Department of Ophthalmology from the Research to Prevent Blindness

491 Foundation.

492

493

494

495 


\section{References}

1. Benga A, Zor F, Korkmaz A, Marinescu B, Gorantla V. The neurochemistry of peripheral nerve regeneration. Indian J Plast Surg. 2017;50(1):5-15. doi: 10.4103/ijps.IJPS_14_17. PubMed PMID: 28615804; PubMed Central PMCID: PMCPMC5469235.

2. Jiang BG, Han N, Rao F, Wang YL, Kou YH, Zhang PX. Advance of Peripheral Nerve Injury Repair and Reconstruction. Chin Med J (Engl). 2017;130(24):2996-8. doi: 10.4103/0366-6999.220299. PubMed PMID: 29237933; PubMed Central PMCID: PMCPMC5742928.

3. Lopez-Cebral R, Silva-Correia J, Reis RL, Silva TH, Oliveira JM. Peripheral Nerve Injury: Current Challenges,ConventionalTreatment.ACSPublications.2017;3.doi:10.1021/acsbiomaterials.7b00655.

4. Makwana M, Raivich G. Molecular mechanisms in successful peripheral regeneration. FEBS J. 2005;272(11):2628-38. doi: 10.1111/j.1742-4658.2005.04699.x. PubMed PMID: 15943798.

5. Gonzalez-Perez F, Udina E, Navarro X. Extracellular matrix components in peripheral nerve regeneration. Int Rev Neurobiol. 2013;108:257-75. doi: 10.1016/B978-0-12-410499-0.00010-1. PubMed PMID: 24083438.

6. Li R, Liu Z, Pan Y, Chen L, Zhang Z, Lu L. Peripheral nerve injuries treatment: a systematic review. Cell Biochem Biophys. 2014;68(3):449-54. doi: 10.1007/s12013-013-9742-1. PubMed PMID: 24037713.

7. Li M, Zhang P, Guo W, Li H, Gu X, Yao D. Protein expression profiling during wallerian degeneration after rat sciatic nerve injury. Muscle Nerve. 2014;50(1):73-8. doi: 10.1002/mus.24082. PubMed PMID: 24123051.

8. Li M, Zhang P, Li H, Zhu Y, Cui S, Yao D. TGF-beta1 is critical for Wallerian degeneration after rat sciatic nerve injury. Neuroscience. 2015;284:759-67. doi: 10.1016/j.neuroscience.2014.10.051. PubMed PMID: 25451291.

9. Kiefer R, Streit WJ, Toyka KV, Kreutzberg GW, Hartung HP. Transforming growth factor-beta 1: a lesion-associated cytokine of the nervous system. Int J Dev Neurosci. 1995;13(3-4):331-9. PubMed PMID: 7572285.

10. Pratt BM, McPherson JM. TGF-beta in the central nervous system: potential roles in ischemic injury and neurodegenerative diseases. Cytokine Growth Factor Rev. 1997;8(4):267-92. PubMed PMID: 9620642.

11. Massague J. TGFbeta signalling in context. Nat Rev Mol Cell Biol. 2012;13(10):616-30. doi: 10.1038/nrm3434. PubMed PMID: 22992590; PubMed Central PMCID: PMCPMC4027049.

12. Assoian RK, Fleurdelys BE, Stevenson HC, Miller PJ, Madtes DK, Raines EW, et al. Expression and secretion of type beta transforming growth factor by activated human macrophages. Proc Natl Acad Sci U S A. 1987;84(17):6020-4. PubMed PMID: 2888109; PubMed Central PMCID: PMCPMC298999. 
13. Ridley AJ, Davis JB, Stroobant P, Land H. Transforming growth factors-beta 1 and beta 2 are mitogens for rat Schwann cells. J Cell Biol. 1989;109(6 Pt 2):3419-24. PubMed PMID: 2557356; PubMed Central PMCID: PMCPMC2115905.

14. Li S, Gu X, Yi S. The Regulatory Effects of Transforming Growth Factor-beta on Nerve Regeneration. Cell Transplant. 2017;26(3):381-94. doi: 10.3727/096368916X693824. PubMed PMID: 27983926; PubMed Central PMCID: PMCPMC5657701.

15. Kimura-Kuroda J, Teng X, Komuta Y, Yoshioka N, Sango K, Kawamura K, et al. An in vitro model of the inhibition of axon growth in the lesion scar formed after central nervous system injury. Mol Cell Neurosci. 2010;43(2):177-87. doi: 10.1016/j.mcn.2009.10.008. PubMed PMID: 19897043.

16. Jeon KI, Hindman HB, Bubel T, McDaniel T, DeMagistris M, Callan C, et al. Corneal myofibroblasts inhibit regenerating nerves during wound healing. Sci Rep. 2018;8(1):12945. doi: 10.1038/s41598018-30964-y. PubMed PMID: 30154512; PubMed Central PMCID: PMCPMC6113331.

17. Silver J, Schwab ME, Popovich PG. Central nervous system regenerative failure: role of oligodendrocytes, astrocytes, and microglia. Cold Spring Harb Perspect Biol. 2014;7(3):a020602. doi: 10.1101/cshperspect.a020602. PubMed PMID: 25475091; PubMed Central PMCID: PMCPMC4355267.

18. Hindman HB, DeMagistris M, Callan C, McDaniel T, Bubel T, Huxlin KR. Impact of topical antifibrotics on corneal nerve regeneration in vivo. Exp Eye Res. 2019;181:49-60. doi: 10.1016/j.exer.2019.01.017. PubMed PMID: 30660507.

19. Rozsa AJ, Beuerman RW. Density and organization of free nerve endings in the corneal epithelium of the rabbit. Pain. 1982;14(2):105-20. PubMed PMID: 7177676.

20. Muller LJ, Marfurt CF, Kruse F, Tervo TM. Corneal nerves: structure, contents and function. Exp Eye Res. 2003;76(5):521-42. PubMed PMID: 12697417.

21. Guthoff RF, Wienss H, Hahnel C, Wree A. Epithelial innervation of human cornea: a threedimensional study using confocal laser scanning fluorescence microscopy. Cornea. 2005;24(5):60813. PubMed PMID: 15968170.

22. Marfurt CF, Cox J, Deek S, Dvorscak L. Anatomy of the human corneal innervation. Exp Eye Res. 2010;90(4):478-92. doi: 10.1016/j.exer.2009.12.010. PubMed PMID: 20036654.

23. Shaheen BS, Bakir M, Jain S. Corneal nerves in health and disease. Survey of Ophthalmology. 2014;59:263 - 85.

24. Yamada N, Matsuda R, Morishige N. Open clinical study of eye-drops containing tetrapeptides derived from substance $\mathrm{P}$ and insulin-like growth factor-1 for treatment of persistent corneal epithelial defects associated with neurotrophic keratopathy. British Journal of Ophthalmology. 2008;92:896-900.

25. Murata Y, Masuko S. Peripheral and central distribution of TRPV1, substance P and CGRP of rat corneal neurons. Brain Research. 2006;1085:87 - 94. 
26. Belmonte C, Garcia-Hirschfeld J, Gallar J. Neurobiology of ocular pain. Progress in Retinal and Eye Research. 1997;16:117-56.

27. Labbe A, Liang $Q$, Wang Z, Zhang $Y, X u L$, Baudouin $C$, et al. Corneal nerve structure and function in patients with non-Shögren dry eye: clinical correlations. Investigative Ophthalmolgy and Visual Science. 2013;54:5144-50.

28. Myrna KE, Pot SA, Murphy CJ. Meet the corneal myofibroblast: the role of myofibroblast transformation in corneal wound healing and pathology. Vet Ophthalmol. 2009;12 Suppl 1:25-7. doi: 10.1111/j.1463-5224.2009.00742.x. PubMed PMID: 19891648; PubMed Central PMCID: PMCPMC3290125.

29. Murueta-Goyena A, Canadas P. Visual outcomes and management after corneal refractive surgery: A review. J Optom. 2018;11(2):121-9. doi: 10.1016/j.optom.2017.09.002. PubMed PMID: 29183707; PubMed Central PMCID: PMCPMC5904824.

30. Calvillo MP, McLaren JW, Hodge DO, Bourne WM. Corneal reinnervation after LASIK: prospective 3-year longitudinal study. Investigative ophthalmology \& visual science. 2004;45(11):3991-6. doi: 10.1167/iovs.04-0561. PubMed PMID: 15505047.

31. Jester JV, Huang J, Fisher S, Spiekerman J, Chang JH, Wright WE, et al. Myofibroblast differentiation of normal human keratocytes and hTERT, extended-life human corneal fibroblasts. Investigative ophthalmology \& visual science. 2003;44(5):1850-8. PubMed PMID: 12714615.

32. Craig AM, Banker G. Neuronal polarity. Annu Rev Neurosci. 1994;17:267-310. doi: 10.1146/annurev.ne.17.030194.001411. PubMed PMID: 8210176.

33. Namba T, Funahashi Y, Nakamuta S, Xu C, Takano T, Kaibuchi K. Extracellular and Intracellular Signaling for Neuronal Polarity. Physiol Rev. 2015;95(3):995-1024. doi:

10.1152/physrev.00025.2014. PubMed PMID: 26133936.

34. Dotti CG, Sullivan CA, Banker GA. The establishment of polarity by hippocampal neurons in culture. J Neurosci. 1988;8(4):1454-68. PubMed PMID: 3282038.

35. Flynn KC. The cytoskeleton and neurite initiation. Bioarchitecture. 2013;3(4):86-109. PubMed PMID: 24002528; PubMed Central PMCID: PMCPMC4201609.

36. Fukata $\mathrm{Y}$, Itoh TJ, Kimura T, Menager C, Nishimura T, Shiromizu T, et al. CRMP-2 binds to tubulin heterodimers to promote microtubule assembly. Nat Cell Biol. 2002;4(8):583-91. doi: 10.1038/ncb825. PubMed PMID: 12134159.

37. Yoshimura T, Kawano Y, Arimura N, Kawabata S, Kikuchi A, Kaibuchi K. GSK-3beta regulates phosphorylation of CRMP-2 and neuronal polarity. Cell. 2005;120(1):137-49. doi: 10.1016/j.cell.2004.11.012. PubMed PMID: 15652488.

38. Hur EM, Zhou FQ. GSK3 signalling in neural development. Nat Rev Neurosci. 2010;11(8):539-51. doi: 10.1038/nrn2870. PubMed PMID: 20648061; PubMed Central PMCID: PMCPMC3533361. 
642

643

661

662

663

664

665

666

667

668

669

670

671

672

673

674

675

676

677

678

679

680

681

39. Woodgett JR. Molecular cloning and expression of glycogen synthase kinase-3/factor A. EMBO J. 1990;9(8):2431-8. PubMed PMID: 2164470; PubMed Central PMCID: PMCPMC552268.

40. Kim WY, Wang X, Wu Y, Doble BW, Patel S, Woodgett JR, et al. GSK-3 is a master regulator of neural progenitor homeostasis. Nat Neurosci. 2009;12(11):1390-7. doi: 10.1038/nn.2408. PubMed PMID: 19801986; PubMed Central PMCID: PMCPMC5328673.

41. Wood JN, Bevan SJ, Coote PR, Dunn PM, Harmar A, Hogan P, et al. Novel cell lines display properties of nociceptive sensory neurons. Proc Biol Sci. 1990;241(1302):187-94. doi: 10.1098/rspb.1990.0084. PubMed PMID: 1979443.

42. Prasad KN. Differentiation of neuroblastoma cells: a useful model for neurobiology and cancer. Biol Rev Camb Philos Soc. 1991;66(4):431-51. PubMed PMID: 1801947.

43. Schubert D, Humphreys S, Baroni C, Cohn M. In vitro differentiation of a mouse neuroblastoma. Proc Natl Acad Sci U S A. 1969;64(1):316-23. PubMed PMID: 4189500; PubMed Central PMCID: PMCPMC286164.

44. LoPresti P, Poluha W, Poluha DK, Drinkwater E, Ross AH. Neuronal differentiation triggered by blocking cell proliferation. Cell growth \& differentiation : the molecular biology journal of the American Association for Cancer Research. 1992;3(9):627-35. PubMed PMID: 1419912.

45. Yin K, Baillie GJ, Vetter I. Neuronal cell lines as model dorsal root ganglion neurons: A transcriptomic comparison. Mol Pain. 2016;12. doi: 10.1177/1744806916646111. PubMed PMID: 27130590; PubMed Central PMCID: PMCPMC4956150.

46. Seeds NW, Gilman AG, Amano T, Nirenberg MW. Regulation of axon formation by clonal lines of a neural tumor. Proc Natl Acad Sci U S A. 1970;66(1):160-7. PubMed PMID: 5273894; PubMed Central PMCID: PMCPMC286102.

47. Schubert D, Humphreys S, Jacob F, de Vitry F. Induced differentiation of a neuroblastoma. Dev Biol. 1971;25(4):514-46. PubMed PMID: 5166556.

48. Zhou J, Holtzman DM, Weiner RI, Mobley WC. Expression of TrkA confers neuron-like responsiveness to nerve growth factor on an immortalized hypothalamic cell line. Proc Natl Acad Sci U S A. 1994;91(9):3824-8. PubMed PMID: 8170995; PubMed Central PMCID: PMCPMC43674.

49. Luo Y, Raible D, Raper JA. Collapsin: a protein in brain that induces the collapse and paralysis of neuronal growth cones. Cell. 1993;75(2):217-27. PubMed PMID: 8402908.

50. Kobayashi H, Koppel AM, Luo Y, Raper JA. A role for collapsin-1 in olfactory and cranial sensory axon guidance. J Neurosci. 1997;17(21):8339-52. PubMed PMID: 9334408.

51. Dontchev VD, Letourneau PC. Nerve growth factor and semaphorin $3 A$ signaling pathways interact in regulating sensory neuronal growth cone motility. J Neurosci. 2002;22(15):6659-69. doi: 20026638. PubMed PMID: 12151545. 
701

702

703

704

705

706

707

708

709

710

711

712

713

714

715

716

717

718

719

720

721

722

723

724

725

726

727

728

729

52. Goslin K, Banker G. Experimental observations on the development of polarity by hippocampal neurons in culture. J Cell Biol. 1989;108(4):1507-16. PubMed PMID: 2925793; PubMed Central PMCID: PMCPMC2115496.

53. Shah SM, Patel CH, Feng AS, Kollmar R. Lithium alters the morphology of neurites regenerating from cultured adult spiral ganglion neurons. Hear Res. 2013;304:137-44. doi:

10.1016/j.heares.2013.07.001. PubMed PMID: 23856237; PubMed Central PMCID: PMCPMC3773701.

54. Jinnin M, Ihn H, Tamaki K. Characterization of SIS3, a novel specific inhibitor of Smad3, and its effect on transforming growth factor-beta1-induced extracellular matrix expression. Mol Pharmacol. 2006;69(2):597-607. doi: 10.1124/mol.105.017483. PubMed PMID: 16288083.

55. Mudge AW. Schwann cells induce morphological transformation of sensory neurones in vitro. Nature. 1984;309(5966):367-9. PubMed PMID: 6727990.

56. Zhou FQ, Zhou J, Dedhar S, Wu YH, Snider WD. NGF-induced axon growth is mediated by localized inactivation of GSK-3beta and functions of the microtubule plus end binding protein APC. Neuron. 2004;42(6):897-912. doi: 10.1016/j.neuron.2004.05.011. PubMed PMID: 15207235.

57. Lavenius E, Gestblom C, Johansson I, Nanberg E, Pahlman S. Transfection of TRK-A into human neuroblastoma cells restores their ability to differentiate in response to nerve growth factor. Cell growth \& differentiation : the molecular biology journal of the American Association for Cancer Research. 1995;6(6):727-36. PubMed PMID: 7669728.

58. Matsushima $\mathrm{H}$, Bogenmann E. Expression of trkA cDNA in neuroblastomas mediates differentiation in vitro and in vivo. Mol Cell Biol. 1993;13(12):7447-56. PubMed PMID: 8246962; PubMed Central PMCID: PMCPMC364816.

59. Solomon F. Specification of cell morphology by endogenous determinants. J Cell Biol. 1981;90(3):547-53. PubMed PMID: 7197278; PubMed Central PMCID: PMCPMC2111906.

60. Han QJ, Gao NN, Guo Q, Zhang ZN, Yu WH, Pan J, et al. IPP5 inhibits neurite growth in primary sensory neurons by maintaining TGF-beta/Smad signaling. Journal of cell science. 2013;126(Pt 2):542-53. doi: 10.1242/jcs.114280. PubMed PMID: 23203807.

61. Lutz M, Krieglstein K, Schmitt S, ten Dijke P, Sebald W, Wizenmann A, et al. Nerve growth factor mediates activation of the Smad pathway in PC12 cells. Eur J Biochem. 2004;271(5):920-31. PubMed PMID: 15009204.

62. Nakashima H, Tsujimura K, Irie K, Ishizu M, Pan M, Kameda T, et al. Canonical TGF-beta Signaling Negatively Regulates Neuronal Morphogenesis through TGIF/Smad Complex-Mediated CRMP2 Suppression. J Neurosci. 2018;38(20):4791-810. doi: 10.1523/JNEUROSCI.2423-17.2018. PubMed PMID: 29695415.

63. Stegmuller J, Huynh MA, Yuan Z, Konishi Y, Bonni A. TGFbeta-Smad2 signaling regulates the Cdh1APC/SnoN pathway of axonal morphogenesis. J Neurosci. 2008;28(8):1961-9. doi: 10.1523/JNEUROSCI.3061-07.2008. PubMed PMID: 18287512. 
64. Anjaneyulu M, Berent-Spillson A, Inoue T, Choi J, Cherian K, Russell JW. Transforming growth factor-beta induces cellular injury in experimental diabetic neuropathy. Exp Neurol. 2008;211(2):469-79. doi: 10.1016/j.expneurol.2008.02.011. PubMed PMID: 18406405; PubMed Central PMCID: PMCPMC2453508.

65. Walshe TE, Leach LL, D'Amore PA. TGF-beta signaling is required for maintenance of retinal ganglion cell differentiation and survival. Neuroscience. 2011;189:123-31. doi: 10.1016/j.neuroscience.2011.05.020. PubMed PMID: 21664439; PubMed Central PMCID: PMCPMC3150228.

66. Leibinger M, Hilla AM, Andreadaki A, Fischer D. GSK3-CRMP2 signaling mediates axonal regeneration induced by Pten knockout. Commun Biol. 2019;2:318. Epub 2019/08/28. doi: 10.1038/s42003-019-0524-1. PubMed PMID: 31453382; PubMed Central PMCID: PMCPMC6707209.

67. Sutherland C. What Are the bona fide GSK3 Substrates? Int J Alzheimers Dis. 2011;2011:505607. doi: 10.4061/2011/505607. PubMed PMID: 21629754; PubMed Central PMCID: PMCPMC3100594.

68. Cole AR, Causeret F, Yadirgi G, Hastie CJ, McLauchlan H, McManus EJ, et al. Distinct priming kinases contribute to differential regulation of collapsin response mediator proteins by glycogen synthase kinase-3 in vivo. The Journal of biological chemistry. 2006;281(24):16591-8. doi: 10.1074/jbc.M513344200. PubMed PMID: 16611631; PubMed Central PMCID: PMCPMC1805471.

69. Uchida Y, Ohshima T, Sasaki Y, Suzuki H, Yanai S, Yamashita N, et al. Semaphorin3A signalling is mediated via sequential Cdk5 and GSK3beta phosphorylation of CRMP2: implication of common phosphorylating mechanism underlying axon guidance and Alzheimer's disease. Genes Cells. 2005;10(2):165-79. doi: 10.1111/j.1365-2443.2005.00827.x. PubMed PMID: 15676027.

70. Eickholt BJ, Walsh FS, Doherty P. An inactive pool of GSK-3 at the leading edge of growth cones is implicated in Semaphorin 3A signaling. J Cell Biol. 2002;157(2):211-7. doi: 10.1083/jcb.200201098. PubMed PMID: 11956225; PubMed Central PMCID: PMCPMC2199247.

71. Saijilafu, Hur EM, Liu CM, Jiao Z, Xu WL, Zhou FQ. PI3K-GSK3 signalling regulates mammalian axon regeneration by inducing the expression of Smad1. Nat Commun. 2013;4:2690. Epub 2013/10/29. doi: 10.1038/ncomms3690. PubMed PMID: 24162165; PubMed Central PMCID: PMCPMC3836055.

72. Millet C, Yamashita M, Heller M, Yu LR, Veenstra TD, Zhang YE. A negative feedback control of transforming growth factor-beta signaling by glycogen synthase kinase 3-mediated Smad3 linker phosphorylation at Ser-204. The Journal of biological chemistry. 2009;284(30):19808-16. Epub 2009/05/22. doi: 10.1074/jbc.M109.016667. PubMed PMID: 19458083; PubMed Central PMCID: PMCPMC2740406. 


\section{Supporting information}

775

776

S1 Fig. Differentiated ND7/23 cells express two different TGF6 receptor subunits (TIF)

777

778

S2 Fig. NGF regulates activation (i.e. phosphorylation) state of GSK-36 in ND7/23 cells (TIF)

779

780

S3 Fig. Effect of NGF, TGF-61, SIS3 and LiCl on 2 different phosphorylation sites on Smad3 (TIF)

781

783 cells (TIF)

784

785

S1 Raw images.

786

787 


\section{Fig 1}

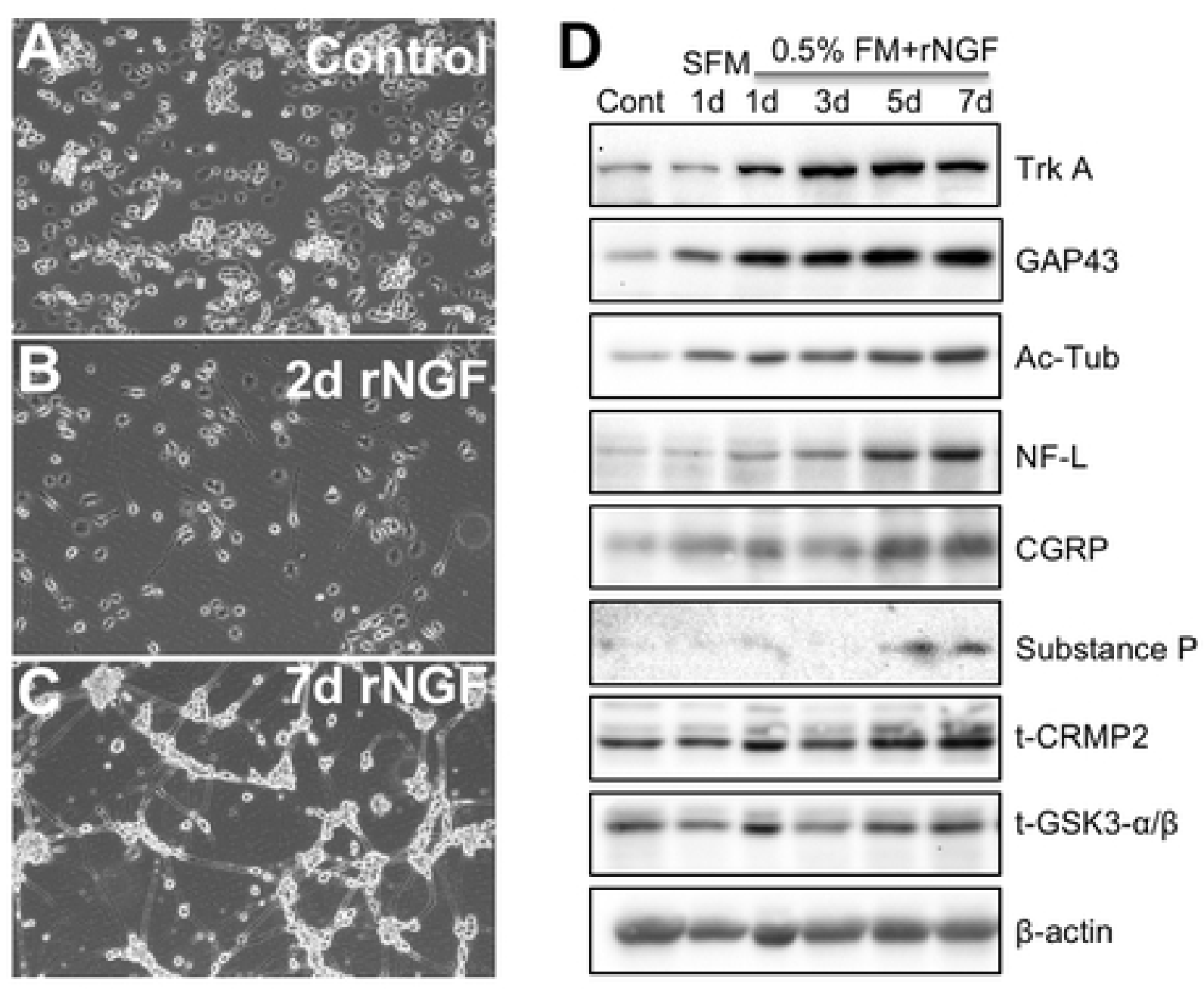

Figure1 

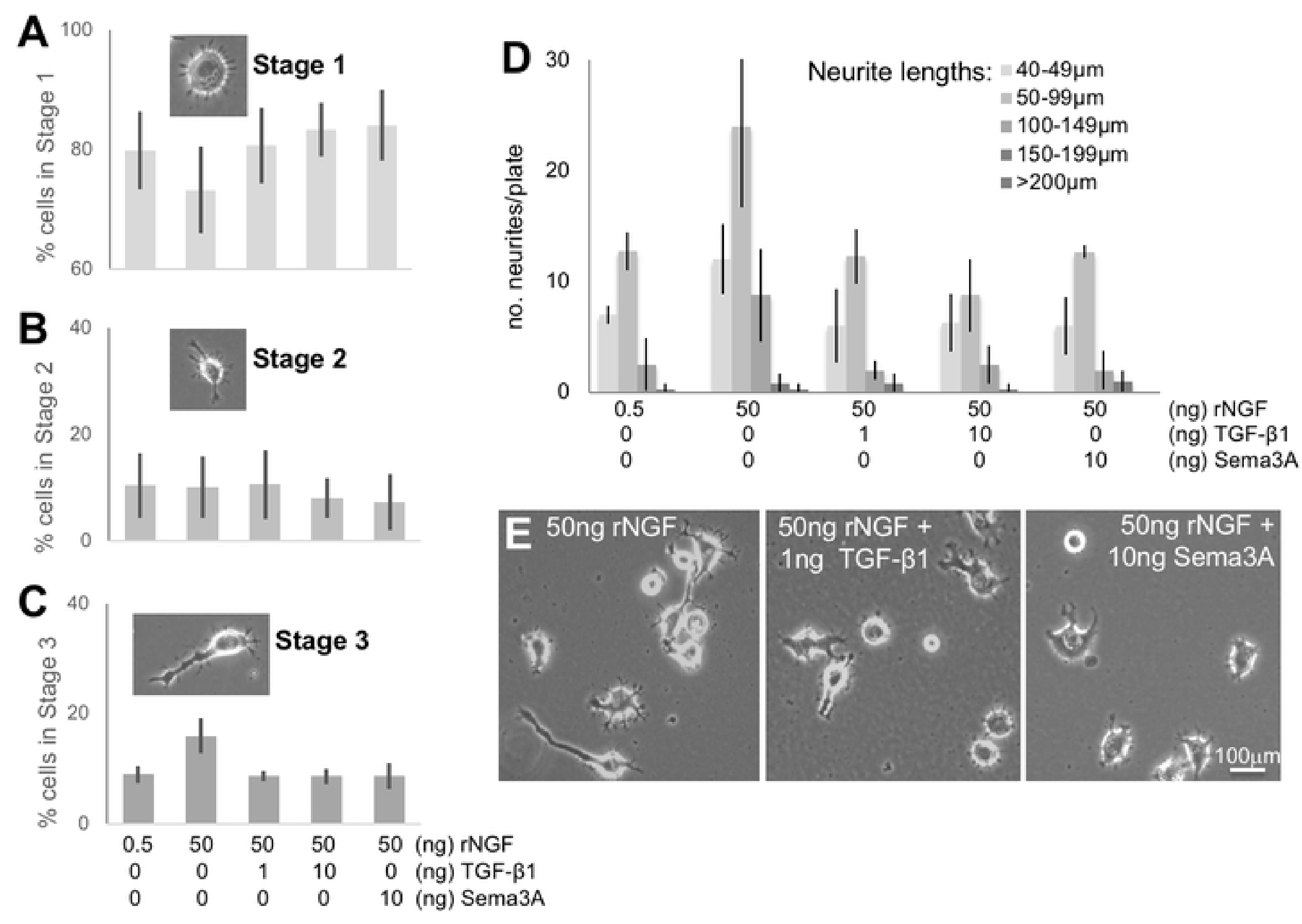

Figure2 
A
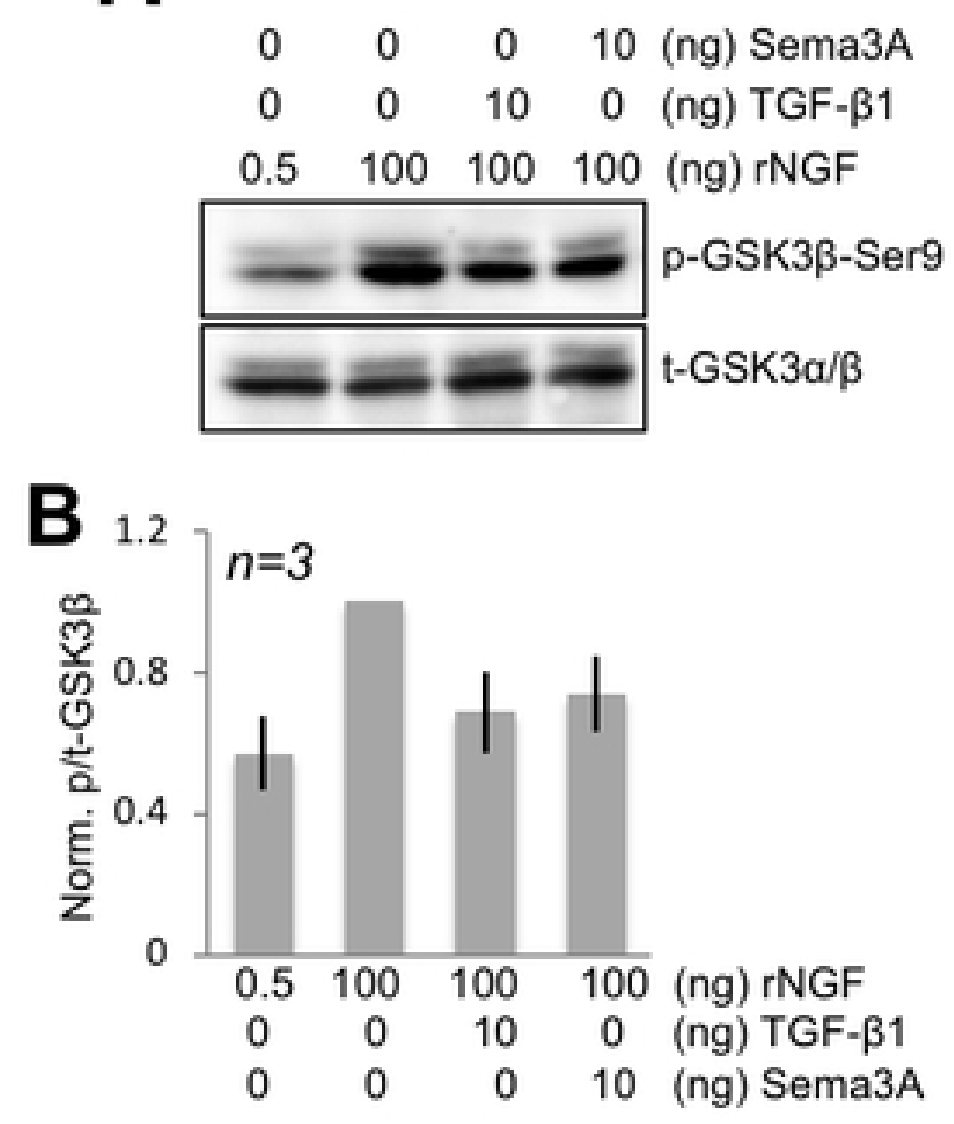

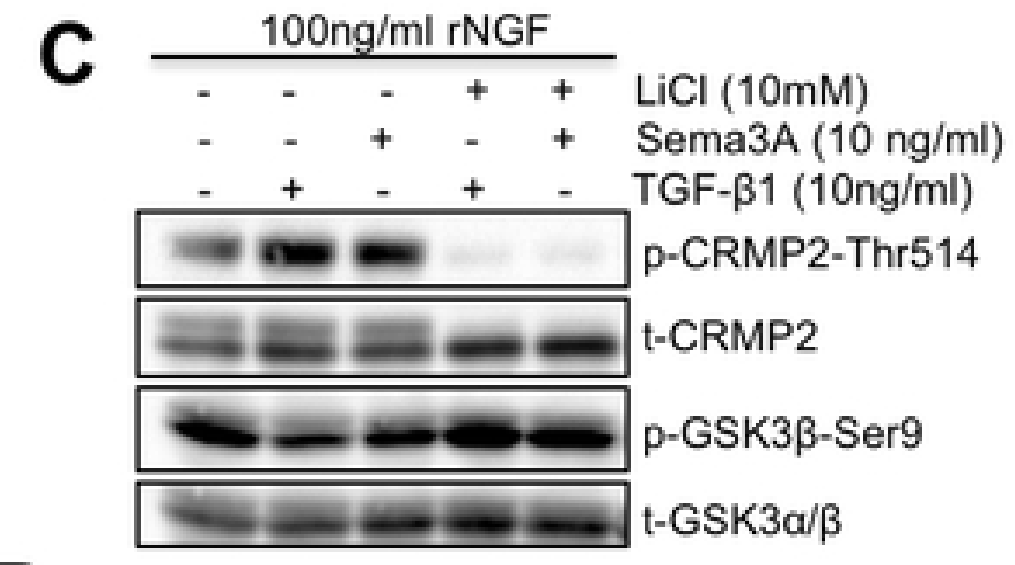

D

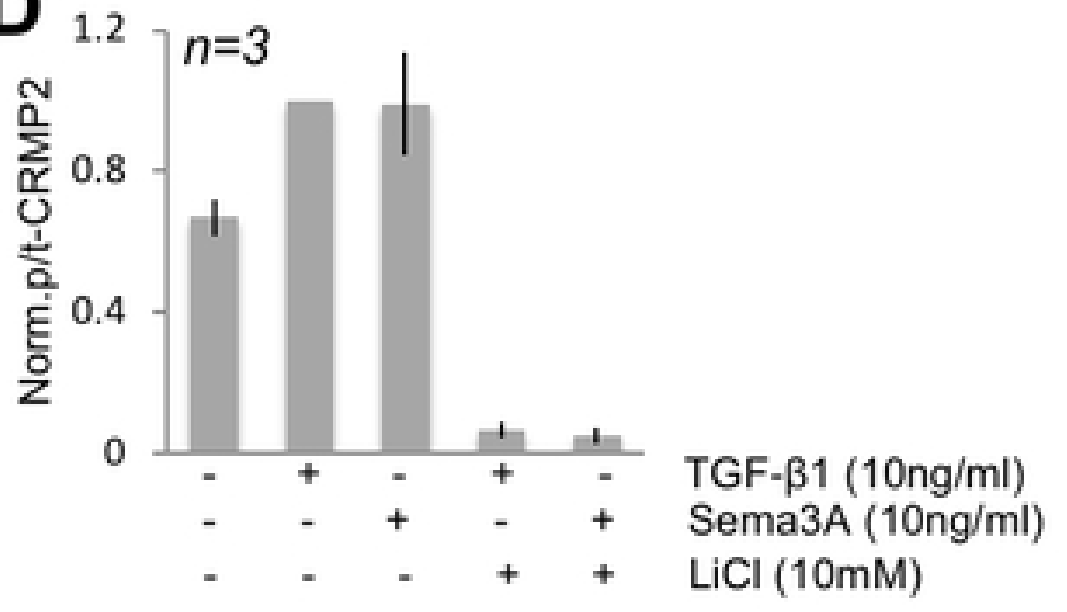

Figure3 


\section{Fig 4}
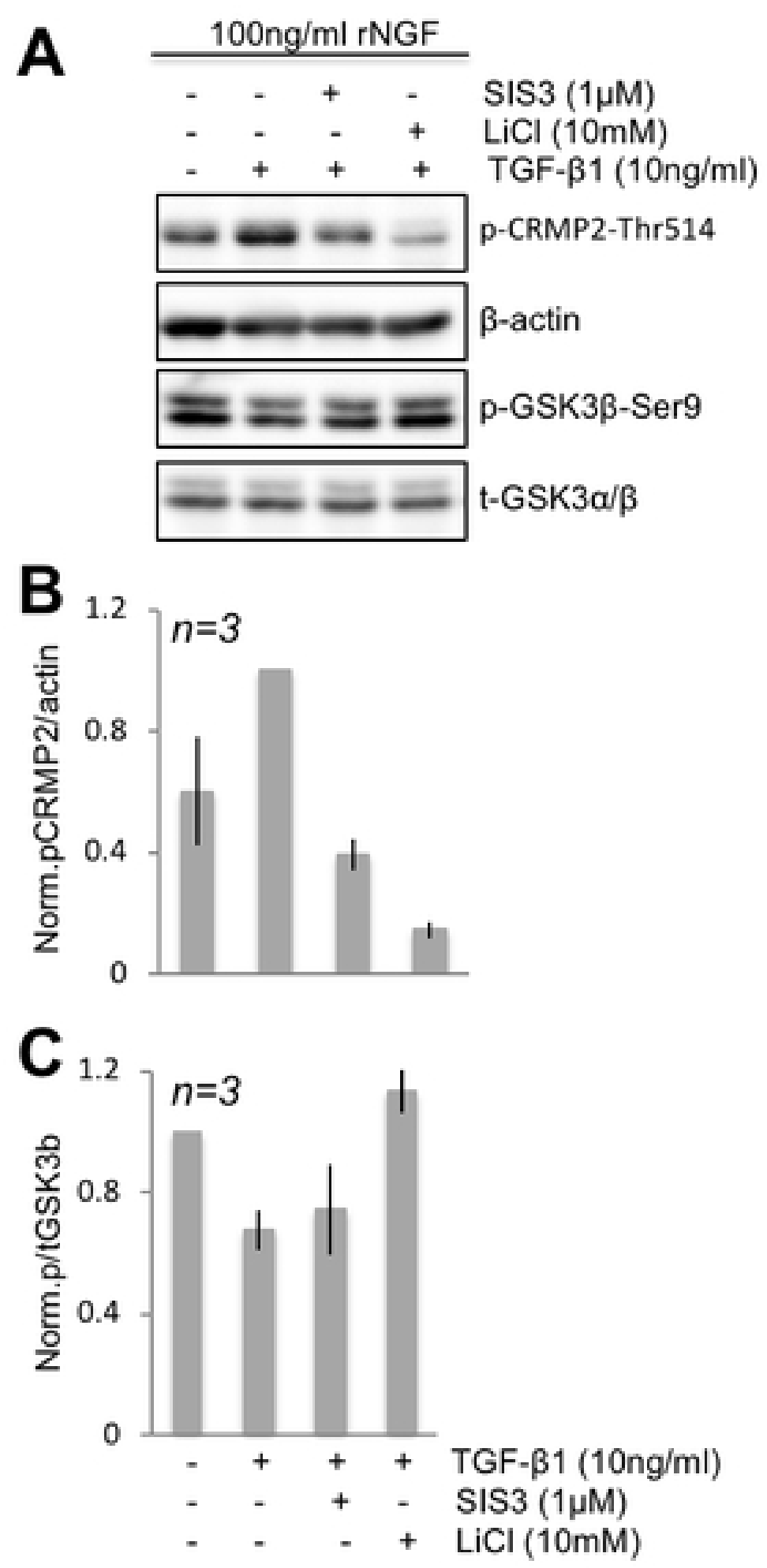

Figure4 
Fig 5

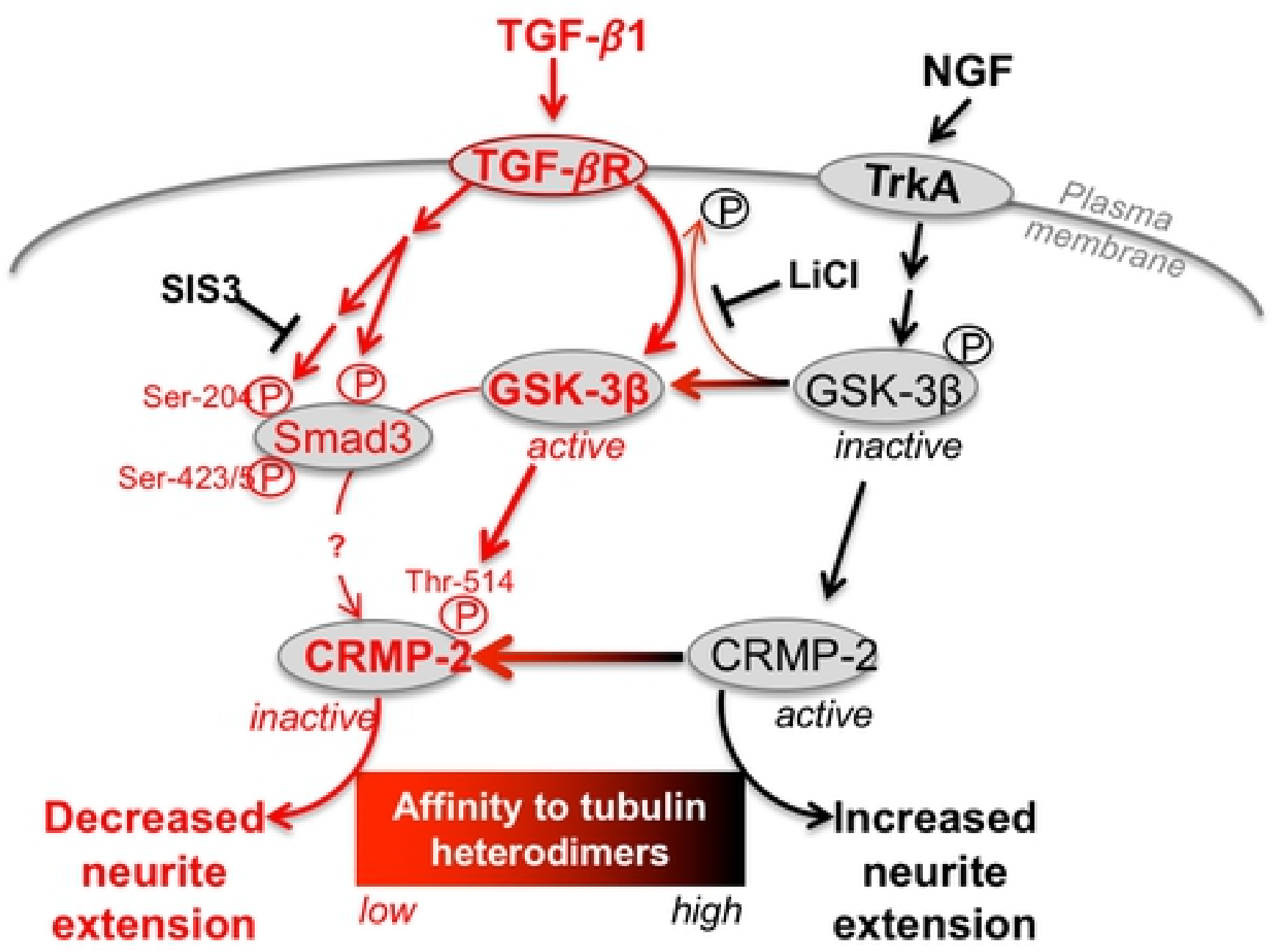

Figure5 